La imagen en el CENTRO de la escena educativa: el Legado de la eXPeriencia de las hermanas Cossettini en Rosario. Páginas 309-312 en Revista de la Escuela de Ciencias de la Educación, año 10, número 9, enero a DICIEMBRE DE 2014. ISSN 1851-6297. ISSN EN LINEA 2362-3349.

\title{
LA IMAGEN EN EL CENTRO DE LA ESCENA EDUCATIVA: EL LEGADO DE LA EXPERIENCIA DE LAS HERMANAS COSSETTINI EN ROSARIO
}

Por Gaspar Tomino (Universidad Nacional de Rosario**, Argentina. gaspartomino@hotmail.com

Recibido: 27/06/2014 Aceptado: 23/07/2014

"Olga y Leticia Cossettini en la Escuela Serena. Cultura, imagen y pedagogía (Rosario, 1935-1950)"

Por María del Carmen Fernández, María Elisa Welti, Rubén Biselli y María Eugenia Guida - $1^{\circ}$ Edición - Rosario: Laborde Libros Editor, Enero de 2014

Fernández, Welti, Biselli y Guida sintetizan diez años de investigación centrados en los aspectos estéticos y pedagógico-sociales de la Experiencia Cossettini en Rosario. El equipo inició las pesquisas en 2003 en el marco de un seminario sobre las hermanas educadoras y su obra en la Escuela "Gabriel Carrasco" entre 1935 y 1950.

Luego de referir los antecedentes y publicaciones en torno al tema, los autores presentan el análisis de la experiencia a partir de un corpus documental nunca antes estudiado, centrado en imágenes y fotografías. También estudian dos textos inéditos de Olga Cossettini escritos en los años '30, contemporáneos al inicio de la experiencia puntual de la Escuela Serena. Proponen así una historización de prácticas y modos de decir y actuar en la escuela a partir de un registro único en cuanto a las fuentes y materiales objeto de estudio; se trata de diarios de docentes, cuadernos de alumnos, fotografías, filmaciones de actividades en y fuera de la escuela, todo en el marco del proyecto educativo llevado adelante por las pedagogas santafesinas.

Los investigadores detallan el marco teórico y metodológico con el cual encararon el análisis de las imágenes, destacando su singular rol en el proceso de enseñanza y su valor cognoscitivo. Esto, indican, trascendió los aspectos meramente estéticos y decorativos para constituirlas en facilitadoras

* Licenciado y profesor universitario en Comunicación Social (UNR). Jefe de Trabajos Prácticos en el Ciclo de Formación Docente (Facultad de Humanidades y Artes, UNR). 
Revista de la Escuela de Ciencias de la Educación, año 10, número 9, enero a diciembre de 2014. Páginas 309-312. ISSN 1851-6297. ISSN EN LINEA 2362-3349. LA IMAGEN EN EL CENTRO DE LA ESCENA EDUCATIVA: EL LEGADO DE LA EXPERIENCIA de las hermanas Cossettini en Rosario. Gaspar Tomino.

de aprendizajes y portadoras de sentido. De allí el análisis exhaustivo tanto de los cuadernos de alumnos, diarios de maestras y planificaciones, como de imágenes de archivo, testimonios de ex alumnos y realizadores audiovisuales que refirieron y/o abordaron la Experiencia. Señalan también la importancia del contexto epocal en que el proyecto educativo investigado tuvo lugar y el rol asumido por las hermanas Cossettini en el panorama no solo pedagógico sino también cultural y social de la Argentina del momento.

El primer apartado del libro nos ubica en la "Serena", su entorno policlasista y los vínculos osmóticos que se establecieron con el mismo, tratando de reconstruir las originales prácticas llevadas adelante a partir de los materiales indagados. La extrañeza del caso es presentada en relación con otras experiencias en el país que se sabe compartieron las ideas escolanovistas (centradas por tanto en el protagonismo del niño), pero que a diferencia del caso de la escuela rosarina, no contaron con la vocación archivista de las hermanas Cossettini. En principio, los investigadores exponen aquí un completo panorama de propuestas y prácticas innovadoras: adaptación edilicia, renovación curricular, excursiones barriales, registro de la experiencia, promoción de la cooperadora y centros de estudiantes y ex alumnos, entre tantas otras. Luego enfatizan el papel vanguardista de la Escuela, ya sea en función de la visibilidad que tomó la Experiencia (por ejemplo, mostrando obras de alumnos en el Museo Municipal de Bellas Artes de Rosario), o bien por el protagonismo asumido por Olga y Leticia en sus intercambios epistolares con figuras de la época, sus viajes y publicaciones; todo esto profusamente ilustrado en las páginas del libro que aquí se reseña.

Un segundo capítulo de la obra se detiene en la articulación entre estética y pedagogía, poniendo en primer plano el registro fotográfico y los cuadernos escolares. Las fotografías seleccionadas por los autores exponen la particularidad del caso en su concepción del niño como ser creativo, junto a la necesidad de generar en la escuela el espacio y las condiciones adecuadas para el respeto y potenciación de sus destrezas. El apartado se nutre con una completa y cuidadosa selección de dibujos y mapas de los cuadernos donde se puede apreciar, al decir de los autores, "la subversión de la relación jerárquica entre palabras e imágenes". Allí, la desaparición de los márgenes o la invasión de la página contigua por una pieza gráfica pone en discusión el dominio del texto escrito por sobre la imagen; el relato pone en el centro de la escena la capacidad de la actividad plástica como vía para el desarrollo de potencialidades y adquisición de competencias.

Complementariamente, el apartado analiza el valor del relato fotográfico encarado por las Cossettini; esto se refiere tanto de las producciones de los alumnos y sus acciones cotidianas dentro de la escuela o en el barrio, como a otras actividades relacionadas con la Experiencia (por ejemplo, los viajes de Olga). En este punto, los investigadores señalan la clara intención de las 
Revista de la Escuela de Ciencias de la Educación, año 10, número 9, enero a diciembre de 2014. Páginas 309-312. ISSN 1851-6297. ISSN EN LINEA 2362-3349. LA IMAGEN EN EL CENTRO DE LA ESCENA EDUCATIVA: EL LEGADO DE LA EXPERIENCIA de las hermanas Cossettini en Rosario. Gaspar Tomino.

hermanas en pos de constituirse como vanguardia pedagógica en el marco del, ya para la época, anquilosado sistema educativo vigente. En este sentido, la profusión de fotografías que retratan la experiencia (y que ilustran ampliamente la obra) constituyen un caso único por su sistematicidad y completitud.

El capítulo final de la publicación resume un último aspecto encarado por las investigaciones del equipo: las actividades de divulgación llevadas adelante desde la Escuela Serena en las denominadas "misiones culturales"; éstas asumieron también un carácter singular en comparación con otras experiencias similares a las que refieren los autores. El contacto de la escuela con los vecinos, la puesta en marcha de las excursiones e incursiones sobre el entorno, destacan el protagonismo de los alumnos (siempre documentado con fotografías seleccionadas), a la vez que ponen de relieve, en palabras de los escritores, "reconfiguraciones del espacio público y la construcción de identidades colectivas".

Para cerrar, los autores marcan puntos de contacto con casos de misiones culturales en España y Uruguay. La experiencia española se propone como un antecedente directo analizado en su momento por la propia Olga Cossettini; sin embargo, se diferencia el caso rosarino en tanto éste involucró únicamente a los niños y sus actividades como agentes divulgadores de los propios proyectos educativos. Para los casos uruguayos estudiados, más allá de las coincidencias con la experiencia abordada, se subraya la particularidad de que contaron con apoyo del gobierno nacional. Aquí, los investigadores dejan en claro que la Escuela Serena y su notable legado nunca lograron superar la condición de "experimental". Ese status, otorgado por el gobierno santafesino en 1935, fue retirado en 1943 al asumir el régimen militar; aun así, el trabajo del equipo de Olga y Leticia logró sostenerse hasta 1950.

Tal como indican los autores, el libro muestra cabalmente lo que se pudo concretar en una década de investigaciones e invita a seguir conociendo y reflexionando sobre esta experiencia, tanto pedagógica como histórica y cultural. 